\title{
What College Freshmen Admit To Not Knowing About Personal Finance
}

Edgar J. Manton, (Email: Edgar_Manton@TAMU-Commerce.edu), Texas A\&M University - Commerce Donald E. English, (Email: Donald_English@TAMU-Commerce.edu), Texas A\&M University - Commerce Stephen Avard, (Email: Steve_Avard@TAMU-Commerce.edu), Texas A\&M University - Commerce Janet Walker, (Email: Janet_Walker@TAMU-Commerce.edu), Texas A\&M University - Commerce

\begin{abstract}
The problem of the study was to determine college freshmen's level of financial knowledge through testing, but also to determine what they admit to not knowing with regard to important financial topics. The entire freshman English 101, College Reading and Writing class at Texas A\&M University-Commerce was surveyed. There were a total of 407 students enrolled in these classes. The highest test score was 80 percent achieved only by one student and lowest was 0 achieved by six students. The average score was $34.8 \%$ for all students and the median score was $32.5 \%$. Unlike previous studies, students were offered the opportunity to respond "don't know" to each question. On 9 of the 20 questions more students selected the "don't know" response than those selecting an incorrect answer.
\end{abstract}

\section{INTRODUCTION}

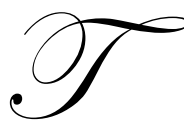

he literature indicates that high school seniors are unprepared to deal with finances when they graduate. The emphasis in the high school curriculum is on preparation for college or on the acquisition of skills to obtain a job and to earn an income. The high school curriculum does not focus on how to effectively use the income in dealing with financial matters such as bank accounts, investments, mutual funds, mortgages, credit cards, loans, Social Security, insurance and taxes. Only if a student has taken a course in consumerism, finance or in economics while in high school would he or she be exposed to topics dealing with every day financial issues.

In 1988, the Texas State Legislature passed a bill mandating that all public high schools implement the Texas Essential Knowledge and Skills for economics with emphasis on the free enterprise system and its benefits. Section 118.2 calls for student understanding in the economics section of market economic systems, supply, demand, consumer economics including risks and rewards, and the impact of investing in the stock and bond markets (Texas Administrative Code, 1998, A2 \& 3).

How effective have these mandates been? The Jumpstart Coalition for Personal Financial Literacy, an organization first convened in 1995 for improving financial literacy among the young, "...determined that the average student who graduates from high school lacks basic skills in the management of personal financial affairs. Many are unable to balance a checkbook and most have no insight into the basic survival principles involved with earning, spending, saving and investing" (http://www.jumpstart.org).

Most tests measuring the financial knowledge of high school students use the typical testing process of truefalse or multiple choice questions which include the correct answer and a false answer or several false answers. The student test scores are derived in the typical fashion based upon $100 \%$. In addition to the traditional approach to test student knowledge, the researchers offered the student the opportunity to admit that he or she did not know the correct answer. This aspect has not previously been explored. Students taking tests are typically forced to select an answer rather than being provided the opportunity to say that they do not know the answer. In addition to measuring student financial knowledge, this study will determine the extent to which the students readily admit not knowing about personal finance topics. 
The purpose of this study, then, is to determine how well recent Texas high school graduates understand basic consumer financial concepts and to ascertain those financial topics for which a significant proportion of students admit to not having knowledge.

\section{HYPOTHESIS}

It is hypothesized that recent Texas high school graduates, who are enrolled in their first year of college, will not have an effective understanding of basic financial concepts dealing with savings, investment and risk. Additionally, it is hypothesized, that significant percentages of students will readily admit that they do not know the correct response to the test questions.

\section{RELATED LITERATURE}

The financial world that college students face is becoming more and more complex. A current newsletter from the National Business Education Association stresses the “....need for sound investing know-how for today's adults." They further state that the "...savings rates in the U.S. are dismal. Students face three long-term financial challenges: buying a home, funding their children's education and planning for retirement" (2003:1-2).

David Wilcox in "Remarks to the Federal Reserve Bank of Dallas in 2000" reported that there would be "roughly 1.2 million personal bankruptcies declared in the United States that year. Further, only two thirds of eligible workers choose to participate in the retirement savings plan sponsored by their employers, even when their employers turbo-charge the plan with a match on employee contributions" (Agency Group 01, 2000). Mr. Wilcox stresses that every graduating senior should understand the concept of limited resources and choices that have to be made concerning opportunity costs, compound interest, and risk.

Jerry Mason (2000) in Educating Consumers, states that consumers are "flunking personal finance" (p. 125). "Personal bankruptcies are at an all-time high. Financial problems are among the primary factors associated in divorce. More elderly people are living in poverty than any other group. And most college graduates are emerging from their ivory towers with debt loads (student loans, auto loans, and credit card debt) substantially greater than their starting salaries" (2000: 125).

Neal Godfrey, (2002) ABA Banking Journal states, “Our kids simply don't learn the financial facts of life... We live in the largest capitalist nation in the world, and our children graduate from high school without a clue about finance. As bankers, educators, and parents, we need to do something about financially illiterate children. Why are we in this situation in the first place? Because we never taught them" (2002: 47).

Some authors question the financial sophisticating of Generation Y. Although Generation Y has "a relatively high level of disposable income", much of the research seems to "indicate that Generation Y consumers have a low degree of financial literacy" (Palmer, Pinto, and Parente, 2001: 105).

In Chen's study, "An Analysis of Personal Financial Literacy among College Students," it is concluded that college students are not knowledgeable about personal finance (Chen, 1998). The low level of knowledge will limit their ability to make informed decisions. Although the respondents were questioned about their knowledge of savings, borrowing, insurance and investments, by far, the weakest area is investments with about 40 percent of the questions answered correctly. Chen concludes, "When individuals cannot manage their finances, it becomes a problem for society. This challenging issue needs to be addressed" (p.107).

In a 2002 article entitled "Gender Differences in Personal Financial Literacy Among College Students," Chen and Volpe (2002) used a large sample (924 usable responses) from multiple colleges and universities in the United States. The study sought to answer questions concerning financial literacy between men and women and their education and experience levels. "Further we find that participants' financial literacy is geared to education and experience factors. Business majors are likely to know more about personal finance than non-business majors. Participants with more years of college experience are more likely to know more about personal finance" (2002: 305). 
The study further found that most individuals learn about financial knowledge through informal channels with 70 percent learning finances from their parents. Only 60 percent learn from college; 30 percent from high school. "Children seek personal finance knowledge from their parents. Yet there is evidence that American adults are themselves not knowledgeable in this area" (2002: 306).

Since 2001, Harris Interactive has produced the 360 Youth College Explorer, a biannual survey of America's college students conducted in conjunction with 360 Youth, the marketing and media arm of Alloy Inc. The 360 Youth College Explorer is the only study of college students conducted among all types of 18 to 30 year old college students, including full-and part-time students, as well as those working toward 2 or 4 year degrees. Following are findings from this study:

- $\quad$ Overall, college students' discretionary purchases total more than $\$ 53$ billion per year.

- $\quad$ Two-thirds of all college students (65\%) have their own credit card, and by their senior year, ownership is 79 percent.

Worries about money are a major theme for today's college students. Half of students worry they may not be able to find a job (52\%). There are too many people living in poverty (51\%) and the economy is weak (49\%). Half depend upon a student loan and these students expect to owe over $\$ 25,000$ upon graduation. (Exploring the College Experience, 2003).

The "2003 CFS Planning and Paying for Higher Education" survey was conducted online for CFS by Harris Interactive, a worldwide market research and consulting firm best known for the Harris Poll. The survey was conducted between April 22, 2003 and May 12, 2003 among 1,062 U. S. College seniors and college graduates. Results of the survey included the following findings. More than half of college graduates (52\% report owing between $\$ 10,000$ and $\$ 40,000$ in student loans. More than one in three $(34 \%)$ college graduates said they were unprepared to make their first monthly student loan payment. Among college graduates surveyed, more than four out of five (83\%) report making monthly credit card payments. More than half of recent graduates (53\%) were unaware of the Federal Consolidation Loan program. (http:/www.harrisinteractive.com/news)(2003).

\section{PROCEDURE}

The entire freshman English 101, College Reading and Writing class at a southern university in the Fall of 2003 was surveyed. There were 25 sections of the course with a total of 407 students enrolled. Twenty multiple choice questions dealing with basic knowledge of financial issues, which should be understood in order to function in everyday life, were prepared by four college of business instructors who have extensive knowledge in their respective fields. Each question had three responses and a fourth response which provided the student the opportunity to respond "don't know ". Of major interest in this study was how many students would select the "don't know" response to each question. Previous studies measuring the financial knowledge of high school students or college graduates have not attempted to determine what students admit to not knowing.

The researchers felt that it was important not to force the respondents to select an answer if they felt that they did not know the correct answer. This approach permitted the students the opportunity to admit not knowing an answer. "Don't know" responses were counted as incorrect answers for test scoring purposes. Each question was valued at 5 points resulting in a total of 100 possible points for all 20 questions.

The questionnaires were delivered to the instructors for each section through the university on-campus mail system. The instructors were requested to administer the test during the first class period of the term. The students were informed that the questionnaire dealt with their knowledge of financial issues. They were told that the survey is anonymous and will not in any way affect their grades. Upon completion of the questionnaires in each class, they were returned to the Literature and Languages Department Office and subsequently returned to the researchers. The questionnaires were delivered and returned over a three day period. The data from the questionnaires were entered into Microsoft Access Database to summarize and analyze the data, to perform queries and to develop findings. 


\section{FINDINGS AND ANALYSIS}

There were 407 students enrolled in the 25 sections of English 101. Of these, 197 were male and 210 were female. The age distribution of the respondents may be seen in Table 1. Seventy-four percent were 18 or under and over $96 \%$ were 24 or less.

Table 1

The Age Distribution for Students Enrolled in English 101 for Fall 2003

\begin{tabular}{ccc}
\hline Age & Number & Percentage \\
\hline$\leq 18$ & 302 & 74.2 \\
$19-24$ & 90 & 22.1 \\
$25-35$ & 14 & 3.4 \\
$36-45$ & 1 & 0.3 \\
\hline Total & 407 & 100.0 \\
\hline
\end{tabular}

\section{Student Test Performance}

The highest test score was $80 \%$ achieved by only one student and only one student scored $75 \%$. The lowest score of 0 was achieved by six students. The average score was $34.8 \%$ for all students and the median score was $32.5 \%$. As expected, the students performed poorly on the test as a whole. Table 2, presents a frequency distribution for the student test scores.

Table 2

Student Test Scores

\begin{tabular}{cccc}
\hline Test score & Number & Percentage & Cumulative Percentage \\
\hline 100 & 0 & 0.0 & 100.0 \\
95 & 0 & 0.0 & 100.0 \\
90 & 0 & 0.0 & 100.0 \\
85 & 0 & 0.0 & 100.0 \\
80 & 1 & 0.1 & 99.9 \\
75 & 1 & 0.3 & 99.6 \\
70 & 3 & 0.7 & 99.3 \\
65 & 13 & 3.2 & 98.9 \\
60 & 12 & 3.0 & 95.7 \\
55 & 26 & 6.4 & 92.7 \\
50 & 40 & 9.8 & 86.3 \\
45 & 43 & 10.6 & 76.5 \\
40 & 43 & 10.6 & 65.9 \\
35 & 38 & 9.3 & 55.3 \\
30 & 47 & 11.5 & 46.0 \\
25 & 41 & 10.1 & 34.4 \\
20 & 38 & 9.3 & 24.4 \\
15 & 24 & 5.9 & 15.0 \\
10 & 14 & 3.4 & 9.1 \\
5 & 17 & 4.2 & 5.7 \\
0 & 6 & 1.5 & 1.5 \\
\hline
\end{tabular}


Slightly more than $92 \%$ of the students scored below $60 \%$, thus failing the test based on a passing score of 60 or above. Forty-Six percent of the students scored 30\% or below. Most of the students' (211 or 52\%) scores were between $30 \%$ and $50 \%$ (inclusive). A total of 290 or about $71 \%$ achieved scores between $20 \%$ and $50 \%$.

\section{Student Performance on Questions}

Table 3, presents each of the 20 questions and the number and percentage of students who answered the questions correctly and incorrectly (including "don't know" responses). On 16 of the questions, more than $50 \%$ answered the questions incorrectly or "don't know". There were only four questions which over $50 \%$ of the students answered correctly $-2,9,10$ and 14 . Thus, the majority of students knew that education is the primary factor to determine income level, that a CD is issued by a bank, the function of disability income insurance, and the function of a $401 \mathrm{~K}$ plan.

The questions answered least correctly were $-4,11,13,14,17$ and 19 with more than $80 \%$ of the students answering the question incorrectly or with a "don't know" response. They did not know how annual interest is invested and compounded, what an initial public offering is, where the stock of a new company would be purchased, the primary advantage of a mutual fund, the cheapest form of life insurance, and the difference between a traditional and a Roth IRA. These are very fundamental financial topics.

The poor performance on the part of the students was in line with what other studies have demonstrated, namely that high school graduates are poorly versed on financial matters. This study, however, goes a step further than others in its attempt to ascertain what recent high school graduates admit to not knowing in the area of personal finance.

Table 3

Students Responses

\begin{tabular}{|c|c|c|c|c|}
\hline \multirow[t]{2}{*}{ Question } & \multicolumn{2}{|c|}{ Correct Responses } & \multicolumn{2}{|c|}{$\begin{array}{l}\text { Incorrect and Don't Know } \\
\text { Responses }\end{array}$} \\
\hline & $\mathbf{N}$ & $\%$ & $\mathbf{N}$ & $\%$ \\
\hline 1. Financial Planning & 203 & 49.9 & 204 & 50.1 \\
\hline 2. Income Level & 305 & 74.9 & 102 & 25.1 \\
\hline 3. Financial Statement & 167 & 41.0 & 240 & 59.0 \\
\hline 4. Compound Interest & 46 & 11.3 & 361 & 88.7 \\
\hline 5. Tax Deductions & 170 & 41.8 & 237 & 58.2 \\
\hline 6. Money market Deposits & 118 & 29.0 & 289 & 71.0 \\
\hline 7. Credit Card Debt Rate & 143 & 35.1 & 264 & 64.9 \\
\hline 8. Home Equity Loan & 89 & 21.9 & 318 & 78.1 \\
\hline 9. Bank Savings & 251 & 61.7 & 156 & 38.3 \\
\hline 10. Disability Insurance & 233 & 57.2 & 174 & 42.8 \\
\hline 11. Initial Public Offering & 65 & 16.0 & 342 & 84.0 \\
\hline 12. IRA Retirement Savings & 170 & 41.8 & 237 & 58.2 \\
\hline 13. Mutual Fund & 64 & 15.7 & 343 & 84.3 \\
\hline 14. Retirement Savings & 238 & 58.5 & 169 & 41.5 \\
\hline 15. Cert. Fin. Planner & 111 & 27.3 & 296 & 72.7 \\
\hline 16. Social Security funds & 107 & 26.3 & 300 & 73.7 \\
\hline 17. Term Life Insurance & 60 & 14.7 & 347 & 85.3 \\
\hline 18. Define Bond & 138 & 33.9 & 269 & 66.1 \\
\hline 19. Roth IRA & 61 & 15.0 & 346 & 85.0 \\
\hline 20. Blue Chip Stock & 101 & 24.8 & 306 & 75.2 \\
\hline
\end{tabular}




\section{Don't Know Responses}

The students were afforded the opportunity to answer "don't know" if they wished on all 20 questions. "Don't know" was the fourth response available on each question. This would eliminate the need to guess if a student did not think that he or she knew the correct answer to a question. The researchers felt it was important to offer the students the opportunity to indicate that they did not know, rather than forcing them to guess and select an answer.

It is interesting to compare the numbers and percentages of students who indicated that they did not know the answers to the questions to those who answered the questions incorrectly. These results are presented in Table 4, which separates the incorrect answers from the "don't know" responses. For example, in question 5, 237 or 58.2\% of the test takers answered with an incorrect or “don't know" response (see Table 3), but the majority of these, 166 or $40.8 \%$ of the test takers indicated that they did not know the answer to the question (see Table 4).

On nine of the 20 questions - 5, 6, 9, 13, 14, 15, 18, 19 and 20 - there were more students responding “don't know" to the question than those students who selected an incorrect response. Almost equal numbers of students chose the "don't know" response on an additional three questions - 2, 7, and 8. The results of this study demonstrate that the students do not possess an adequate level of financial knowledge to function in society, but they also demonstrate that the students, for the most part, recognize their lack of personal finance acumen.

Table 4

Students Responding Incorrect and "Do not know"

\begin{tabular}{|c|c|c|c|c|}
\hline \multirow[t]{2}{*}{ Questions } & \multicolumn{2}{|c|}{ Incorrect } & \multicolumn{2}{|c|}{ Do not know } \\
\hline & $\mathbf{N}$ & $\%$ & $\mathbf{N}$ & $\%$ \\
\hline 1. Financial Planning & 188 & 46.2 & 16 & 3.9 \\
\hline 2. Income Level & 53 & 13.0 & 49 & 12 \\
\hline 3. Financial Statement & 203 & 49.9 & 37 & 9.1 \\
\hline 4. Compound Interest & 242 & 59.5 & 119 & 29.2 \\
\hline 5. Tax Deductions & 71 & 17.4 & 166 & 40.8 \\
\hline 6. Money Market Deposits & 94 & 23.1 & 195 & 47.9 \\
\hline 7. Credit Card Debt Rate & 140 & 34.4 & 124 & 30.5 \\
\hline 8. Home Equity Loan & 165 & 40.5 & 153 & 37.6 \\
\hline 9. Bank Savings & 73 & 17.9 & 83 & 20.4 \\
\hline 10. Disability Insurance & 119 & 29.2 & 55 & 13.5 \\
\hline 11. Initial Public Offering & 197 & 48.4 & 145 & 35.6 \\
\hline 12. IRA Retirement Savings & 137 & 33.7 & 100 & 24.6 \\
\hline 13. Mutual Fund & 120 & 29.5 & 223 & 54.8 \\
\hline 14. Retirement Savings & 44 & 10.8 & 125 & 30.7 \\
\hline 15. Cert. Fin. Planner & 138 & 33.9 & 158 & 38.8 \\
\hline 16. Social Security funds & 184 & 45.2 & 116 & 28.5 \\
\hline 17. Term Life Insurance & 223 & 54.8 & 124 & 30.5 \\
\hline 18. Define Bond & 95 & 23.3 & 174 & 42.8 \\
\hline 19. Roth IRA & 65 & 16.0 & 281 & 69.0 \\
\hline 20. Blue Chip Stock & 99 & 24.3 & 207 & 50.9 \\
\hline
\end{tabular}


Table 5 places the percentage of "don't know" responses to a question from the highest percentage to the lowest percentage. The "don't know" responses for the test takers ranges from a low of $3.9 \%$ for question 1, "the purpose of financial planning," to a high of $69 \%$ on question 19, admitting not knowing "the difference between a traditional IRA and a Roth IRA".

Table 5

Do Not Know Response by Rank (High to Low)

\begin{tabular}{llccc}
\hline \multicolumn{1}{c}{ Question } & Q\# & Do not know & \% \\
\cline { 3 - 5 } & & 19 & 281 & 69.0 \\
2 & Roth IRA & 13 & 223 & 54.8 \\
3 & Mutual Fund & 20 & 207 & 50.9 \\
4 & Money Market Deposits & 6 & 195 & 47.9 \\
5 & Define Bond & 18 & 174 & 42.8 \\
6 & Tax Deductions & 5 & 166 & 40.8 \\
7 & Cert. Financial Planner & 15 & 158 & 38.8 \\
8 & Home Equity Loan & 8 & 153 & 37.6 \\
9 & Initial Public Offering & 11 & 145 & 30.7 \\
10 & Retirement Savings & 14 & 125 & 30.5 \\
11 & Credit Card Debt Rate & 7 & 124 & 30.5 \\
12 & Term Life Insurance & 17 & 124 & 29.2 \\
13 & Compound Interest & 4 & 119 & 28.5 \\
14 & Social Security funds & 16 & 116 & 24.6 \\
15 & IRA Retirement Savings & 12 & 100 & 20.4 \\
16 & Bank Savings & 9 & 83 & 13.5 \\
17 & Disability Insurance & 10 & 55 & 12.0 \\
18 & Income Level & 2 & 49 & 9.1 \\
20 & Financial Statement & Financial Planning & 37 & 16 \\
\end{tabular}

On three of these 20 questions - 13, 19 and 20, over 50\% admitted not knowing the answer. Question 19, which asked for the difference between a Roth IRA and a traditional IRA, had 69\%"don't know responses." More than 54\% of the students indicated that they did not know the major purpose of buying mutual funds as opposed to individual stocks in their response to question 13. Question 20 looked for the definition of a blue chip stock and $50.9 \%$ answered "don't know". On 3 more questions - 5, 6 and 18 - between 40 and 50\% admitted not knowing the answer to the question. Question 5 that dealt with the reason to take the standard deduction in income tax. Question 6 was looking for the advantage of a money market account over a bank savings account. Question 18 dealt with the definition of a bond. On six additional questions - 7, 8, 11, 14, 15 and 17 between 30 and $40 \%$ admitted not knowing the answer. Overall, a minimum of $20 \%$ responded "don't know" to 16 of the 20 questions.

\section{Gender Responses}

Table 6 categorizes the percentage of "don't know" and incorrect responses by gender. It is interesting to note that of the 20 questions a higher percentage of females answered "don't know" than the males on 18. For the majority of the questions, the percentage differences were small and within 5 percentage points. But for nine questions, the differences were larger. These were: $-2,4,6,11,13,17,18,19$ and 20.The differences in these questions where all statistically significant at least at a $10 \%$ level of significance. 
Nine percent of the male students responded "don't know" to question \#2 dealing with the primary factor to determine income level compared to $14.8 \%$ of the females. In question 4, a higher percentage of males felt that they were able to select an answer to the question dealing with how interest is compounded than females, i.e. $22.3 \%$ "don't know" responses for the males vs. 35.7\% for the females. A much higher percentage of females responded "don't know" to question 6 dealing with money market deposits than males (males "don't know" - 41.6\%; females - 53.8\%). In question 11, dealing with an initial public offering, $25.9 \%$ of the males answered that they did not know the answer while $44.8 \%$ of the females so responded. Well over half (63.8\%) of the females indicated "don't know" to the main advantage of a mutual fund compared to $45.2 \%$ of the males in question 13. Question 17 dealt with the most appropriate type of life insurance for young persons. Thirty four percent of the females responded "don't know" compared to $26.4 \%$ of the males. There was an $11 \%$ difference between males and females responding "don't know" to question 18, which called for the respondent to identify the definition of a corporate bond. For question 19, the majority of both males and females indicated that they did not know the difference between a Roth IRA and a traditional IRA, i.e. $61.4 \%$ of the males composed to $76.2 \%$ of the females. Sixty-four percent of the females and $36.5 \%$ of the males responded "don't know" to question 20 regarding the definition of a blue chip stock.

The males responded "don't know" more than selecting the incorrect answer on nine of the 20 questions - 5, $6,9,13,14,15,18,19$ and 20. More females responded "don't know" rather than selecting an incorrect answer on thirteen of the questions $-2,5,6,7,8,9,11,13,14,15,18,19$ and 20 . The nine questions for the males were common to the thirteen questions for the females. On all of these 9 questions there was a higher percentage of "don't know" response by the females than males.

With females selecting the "don't know" response more frequently than the males, one might expect their incorrect answer percentages to be lower than the males. The males had higher incorrect answer percentages than the females on 15 of the 20 questions

Table 6

Incorrect and Don't Know Response Percentage By Gender

\begin{tabular}{lcccc}
\hline \multicolumn{1}{c}{ Question } & \multicolumn{2}{c}{ Male } & \multicolumn{2}{c}{ Female } \\
\cline { 2 - 5 } & $\begin{array}{c}\text { \% } \\
\text { Incorrect }\end{array}$ & \%Don't Know & $\begin{array}{c}\text { \% } \\
\text { Incorrect }\end{array}$ & \%Don't Know \\
\hline 1.Financial Planning & 43.7 & 4.1 & 48.6 & 3.8 \\
2.Income Level & 14.2 & 9.1 & 11.9 & $14.8^{* * *}$ \\
3. Financial Statement & 48.2 & 10.2 & 51.4 & 8.1 \\
4.Compound Interest & 64.5 & 22.3 & 54.8 & $35.7^{*}$ \\
5.Tax Deductions & 15.2 & 37.6 & 19.5 & 43.8 \\
6. Money Market Deposits & 25.9 & 41.6 & 20.5 & $53.8^{* *}$ \\
7.Credit Card Debt Rate & 39.6 & 27.4 & 38.5 & 33.3 \\
8.Home Equity Loan & 43.1 & 34.0 & 17.6 & 41.0 \\
9.Bank Savings & 18.3 & 19.3 & 30.0 & 21.4 \\
10.Disability Insurance & 28.4 & 12.2 & 39.0 & 14.8 \\
11.Initial Public Offering & 58.4 & 25.9 & 32.9 & $44.8^{*}$ \\
12.IRA Retirement Savings & 34.5 & 23.4 & 21.0 & 25.7 \\
13.Mutual Fund & 41.1 & 45.2 & 10.5 & $63.8^{*}$ \\
14.Retirement Savings & 11.2 & 28.4 & 34.8 & 32.9 \\
15.Cert. Fin. Planner & 33.0 & 37.6 & 42.9 & 40.0 \\
16.Social Security funds & 47.7 & 25.9 & 47.1 & 31.0 \\
17.Term Life Insurance & 62.9 & 26.4 & 20.0 & $34.3^{* * *}$ \\
18.Define Bond & 26.9 & 37.1 & 12.9 & $48.1 * *$ \\
19.Roth IRA & 19.3 & 61.4 & 17.6 & $76.2^{*}$ \\
20.Blue Chip Stock & 31.5 & 36.5 & & $64.3^{*}$ \\
\hline * p<.01 & & & &
\end{tabular}




\section{SUMMARY AND CONCLUSIONS}

The entire fall 2003 semester freshman class enrolled in English 101, College Reading and Writing classes at a southern university was administered a questionnaire containing 20 questions dealing with financial matters. This included 407 students, all of whom responded. Questions on age and gender, as well as those questions to measure student financial knowledge, were included. Of special interest in the study was to be the student's willingness to admit to not knowing the answer to a question. Thus, each question offered the student the opportunity to respond "don’t know."

From the test scores achieved by the freshman students, it is apparent that they have a low level of understanding concerning financial concepts dealing with investing, saving and risk. The highest score on the test was $80 \%$ with the average score being $34.8 \%$. Ninety-two percent of the students failed the exam based a passing score of $60 \%$. These results agree with previous studies.

In this study, the students could select a "don't know" response. The extent that the students afforded themselves the opportunity to respond "don't know" to the questions was somewhat higher than expected. On 9 of the 20 questions more students selected the "don't know" response than those selecting an incorrect answer. Over $30 \%$ of the students responded "don't know" to 12 of the 20 questions and overall more than $20 \%$ responded "don't know" to 16 of the questions. Of significance was that almost $70 \%$ of the students admitted to not knowing the difference between a traditional and Roth IRA and that more than 50\% of the students reported not knowing the main purpose of a mutual fund and the definition of a blue chip stock. Considering gender, females responded "don't know" in a higher percentage than males for 18 of the 20 questions.

The results on the test indeed validate the fact that recent high school graduates are not knowledgeable about everyday financial matters. It is felt that the extent to which the students openly admitted not knowing the answer to a question is significant. It is encouraging that these students recognize and admit their lack of the financial knowledge necessary to function in their lives. It would seem that the appropriate place to resolve this issue would be at the high school level. However, in spite of the state of Texas mandating a course in free enterprise at the high school level, the results of this test demonstrate a deficiency in this area. It is very important that a college graduate be able to interact with the financial industry in dealing with insurance, mortgages, investments and tax issues.

Perhaps colleges and universities need to take the approach that they have when enrolling students who lack math skills, i.e. after performing poorly on a math entrance test, students are given the opportunity or indeed are required to take a remedial math course. Perhaps the same approach should be taken for financial knowledge, i.e. to develop a remedial program. For those students who are lacking knowledge in personal finance topics. Or, since this subject matter is so important to college graduates during their entire lives, perhaps universities should regard financial knowledge as being a component of their general education program and require a course in personal finance of all of its students.

\section{REFERENCES}

1. Agency Group 01. 2000. Importance of improving financial proficiency of young people treasury assistant secretary for economic policy David W. Wilcox remarks to the Federal Reserve Bank of Dallas, Dallas, Texas. FDCH Regulatory Intelligence Database. 11/13/2000.

2. Chen, H.(1998). An analysis of personal financial literacy among college students. Financial Services Review. Vol. 7 Issue 2, 107-129.

3. Chen, Haiyand \&Volpe, Ronald P. (2002). Gender differences in personal financial literacy among college students. Financial Services Review, 11, 289-307.

4. $\quad$ Exploring the college experience. (2004, March). Trends \& Tudes, 2, 1.

5. $\quad$ Godfrey, Neal (April, 2002). The 'dud' generation. ABA Banking Journal. 94 (4) 47.

6. Harris interactive poll. (2003, March). Retrieved May 21, 2004, from http://www.harrisinteractive.com/news

7. Jump Start Coalition Homepage. Retrieved May $7^{\text {th }}$, 2004, from http://www.jumpstart.org

8. Mason, J. (2000). Educating Consumers. Advisor Today, Vol. 95 Issue 2, 125-130. 
9. Palmer, T. S., Pinto, M. B., \& Parente, D. H. (2001). College Students' Credit Card Debt and the Role of Parental. Journal of Public Policy \& Marketing, Vol. 20 Issue 1, 105-114.

10. Stock Market Savvy. (2003) National Business Education Association, Vol. 14 No. 6.

11. Texas Administrative Code, Title 19, Part II, Chapter 118, Texas Essential Knowledge and Skills for Economics with Emphasis on the Free Enterprise System and Its Benefits (Austin, 1998), 2-3.

12. Texas Education Agency, Economics Education: A State Assessment in Texas (Austin, Texas: 1979), 1.

\section{APPENDIX A: SURVEY QUESTIONS}

\section{Personal Finance Questionnaire}

Gender: $\quad$ Male

Female

What is your age: 18 or under

$19-24$

$25-35$

$36-45$

over 45

Have you ever taken an Economics or Personal Finance course in high school or college?

Yes No

Please Circle Your Response To Each Of The Following Questions.

1. The main reason for personal financial planning is to:
a. know your spending
b. determine your insurance needs
c. achieve financial goals
d. don't know

2. The primary factor to determine your income level is
a. who you know
b. your age
c. education attained
d. don't know

3. You start to measure your financial condition by:
a. preparing a listing of all sources of income
b. creating a listing of all assets and liabilities
c. determining how much you owe on credit cards
d. don't know

4. Annual interest is reinvested and compounded
a. each year on the anniversary of the account
b. at the end of the fiscal year
c. at the end of the calendar year
d. don't know

5. A person uses itemized deductions rather than take the standard deduction for federal income tax calculation for the following reason:
a. filing jointly makes it more feasible
b. it is easier to calculate
c. lower taxes may result
d. don't know 
6. The advantage of Money Market Deposit Accounts over bank saving accounts is
a. greater accessibility
b. more frequent statements
c. variable rates that are generally higher
d. don't know

7. The average non-introductory interest rate on credit card debt is
a. $10 \%$
b. $15 \%$
c. $20 \%$
d. don't know

8. Home equity loans have two advantages over most consumer loans. They are
a. lower interest rates and tax deductible
b. quarterly payments and longer terms
c. longer payment terms and monthly payments
d. don't know

9. A certificate of deposit (CD) is issued by
a. banks
b. corporations
c. U.S. Government
d. don't know

10. Insurance that provides payment in the event of income being interrupted by sickness, illness or accident is called
a. liability insurance
b. disability insurance
c. unemployment insurance
d. don't know

11. English wants to invest in a newly issued stock of a fast growing new company. The market he will trade in is the
a. international market
b. New York Stock Exchange
c. primary market
d. don't know

12. Personal savings plan that allows you to set aside money for retirement, while offering you tax advantages is
a
a. IRA
b. coupon
c. savings bond
d. don't know

13. Mutual fund investing has the advantage over buying individual stocks of
a. liquidity
b. professional management
c. minimal transactions costs
d. don't know 
14. The defined contribution retirement plan that matches the employer's contribution to the employee's contribution to his or her retirement account is the
a. profit sharing plan
b. employee stock ownership plan
c. $\quad 401(\mathrm{k})$ plan
d. don't know

15. A professional designation for advisors focusing on personal financial advice is
a. chartered financial analyst
b. certified public accountant
c. certified financial planner
d. don't know

16. Social Security retirement is:
a. funded by contributions from the employee and employer which are placed into named accounts identified for each employee to be used when they retire.
b. funded by contributions from the employee only which are placed into an account for the employee to be used when they retire.
c. funded by contributions from the employee and the employer which are then transferred to current retirees for monthly retirement payments.
d. don't know.

17. For a young person wishing to have the highest coverage of life insurance for a given dollar amount, the most appropriate type of insurance would be
a. whole life insurance
b. liability insurance
c. term insurance
d. don't know

18. A corporate debt instrument that is a promise to provide interest payments and to repay the principal on a specified date (maturity).
a. stock
b. treasury bill
c. bond
d. don't know

19. The major difference between Roth IRA and traditional IRA is:
a. earnings are higher with a Roth IRA.
b. you can invest more money in a Roth IRA.
c. at retirement, funds from a Roth IRA can be withdrawn tax free.
d. don't know.

20. A blue chip stock is the stock of a
a. new technology stock
b. a large well know company
c. a defensive industry stock
d. don't know 